\title{
Screening of Y-STR INRA189 polymorphism in Indian breeds of Buffaloes
}

\author{
Siddharth Deswal ${ }^{1}$, Sanjeev Singh ${ }^{2}$, Jeevan C ${ }^{3}$, Indrajit Ganguly ${ }^{4}$, S P Dixit ${ }^{5}$, Sanjay Kumar ${ }^{6}$
}

Received: 13 May 2019 / Accepted: 21 May 2019 / Published online: 27 August 2019

(C) Indian Dairy Association (India) 2019

\begin{abstract}
In present study weexplore Y specific STR INRA189 polymorphism in Indian breeds of buffaloes. A total of 139 semen samples of five different Indian buffalo breeds were collected for the study. DNA was extracted using standard phenol chloroform method. Previously reported fluorescent labelled primer were standardised at annealing temperature of $58^{\circ} \mathrm{C}$ for PCR amplification. Further, the genotyping was done using capillary electrophoresis on ABI 3730 instruments (Applied Biosystems) and data was analysed in GeneMapper software.With previously reported allele size range in cattle and African buffalo, the microsatellite marker INRA189 was found to have only one allele of $173 \mathrm{bp}$ size in all five breeds of buffalo (Murrah, Mehsana, Nili-Ravi, Surti and Jaffarabadi). INRA189 Y specific STR was found to be monomorphic in Indian breeds of buffalo.
\end{abstract}

Keyword: INRA189, Jaffarabadi, Murrah, Mehsana, Nili-Ravi, Polymorphism, Surti,

India is well known for rich genetic resources in terms of its buffalo breeds. India is the home tract for some of the best buffalo breeds like Murrah, Jaffarabadi, Surti, Mehsana, Nagpuri etc. There are 16 registered breeds of buffalo in India namely Murrah, Mehsana, Jaffarabadi, Nili-Ravi, Bhadawari, Marathwadi, Nagpuri, Pandharpuri, Surti, Toda, Banni, Chilika, Kalahandi, Luit,

Siddharth Deswal ${ }^{1}(\varangle)$, Sanjeev Singh ${ }^{2}$, Jeevan $C^{3}$, Indrajit Ganguly ${ }^{4}$, S P Dixit $^{5}$, Sanjay Kumar

${ }^{1,3}$ ICAR-National Dairy Research Institute, Karnal - 132001 (Haryana) India

Email: siddharthdeswal25@gmail.com; Ph: +919671973124

2,4,5ICAR-National Bureau Animal Genetic Recourses, Karnal - 132001 (Haryana) India

${ }^{6}$ ICAR-Central Institute for Research on Buffaloes (CIRB), Sub-campus, Nabha -147 201 (Punjab) India
Bargur and Chhattisgarh NBAGR (2019). Buffaloes are the back bone of the dairy industry in India, providing a source of milk, meat, skin, hides, fertilizers, fuel, and draft power. Buffalo contributes about $21.23 \%$ of the total livestock population in India. Its population has increased by $3.06 \%$ during $2007-12$ with a total of 108.7 million heads (Livestock census, 2012). India continues to be the largest producer of milk in the world. Milk production during 2015-16 and 2016-17 was 155.5 and 165.4 million tons, respectively; depicting an annual growth of $6.36 \%$. Buffalo contributes about $49.2 \%$ of total milk production ( 81.37 million ton). In 2016-17, buffalo contributes about 1.46 million tons of meat i.e., to the tune of $19.83 \%$ of total ( 7.4 million tons) meat production of the country (BAHS 2017).

Recently, the rapid urbanization and increase demand of animal products, and to meet this trend of modernization there is uncontrolled breeding between well-defined breeds which results in the depletion of genetic variability. Future improvement is dependent on genetic variation in breeds. Recent developments in molecular genetics led to detection of genetic polymorphism at the DNA sequence level using molecular markers.Y chromosome, the uniparental molecular marker, has been widely used to resolve the questions about origin, prehistorical range expansions and demographic processes in domestic animals. Even with advancement of whole genomic approaches to study the livestock complexity, the $\mathrm{Y}$ chromosome has an edge over others, because of its unique pattern of inheritance Luikart et al. (2001). In domestic animals, the effective $\mathrm{Y}$ chromosome contribution tends to decrease because of repeated use of few selected males in breeding schemes that tends to produce large number of offspring Hellborg et al. (2004). Recently, a large number (38) of polymorphic $\mathrm{Y}$ chromosomal microsatellites have been developed for cattle (Bostaurus) Liu et al. (2002). They have an edge over other genetic markers for comparative studies of evolution, genetic variation, parentage assessment and gene flow. Due to their highly polymorphic nature, microsatellites which consist of tandemly repeated short DNA sequences, have proved to be sensitive markers for population genetics studies Bruford et al. (1993).

INRA189 Y-STR has male specificity and has localization on the Y specific region in cattle Liu et al. (2003). INRA189 had been 
Fig. 1: Allele in INRA189 found in different buffalo breeds

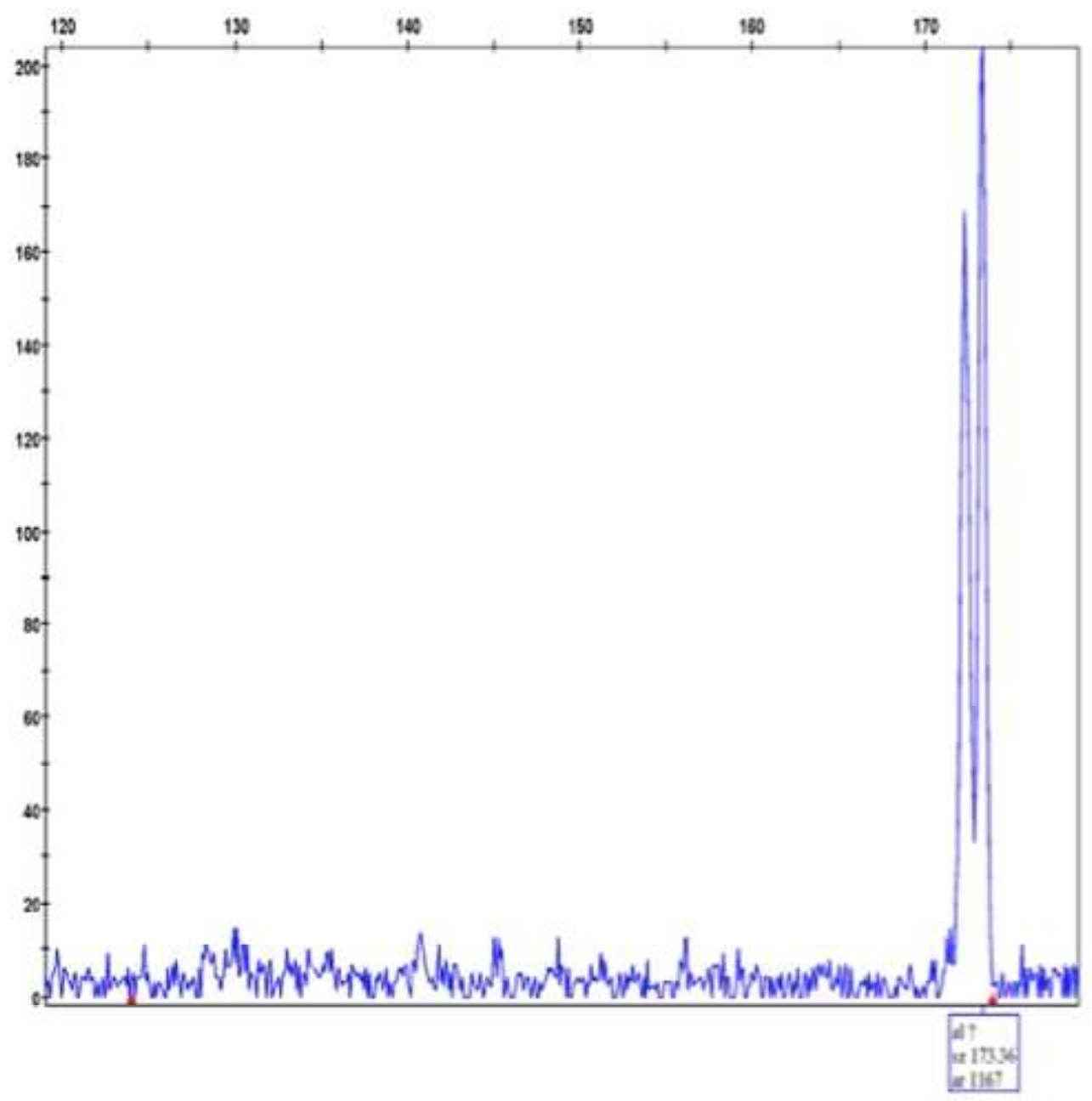

Table 1 Sequence of INRA189 primer, Annealing temperature and allele size range

\begin{tabular}{llllr}
\hline $\begin{array}{l}\text { Locus } \\
\text { Name }\end{array}$ & $\begin{array}{l}\text { Primer sequence } \\
\left(5^{\prime}-3^{\prime}\right)\end{array}$ & $\begin{array}{l}\text { Annealing } \\
\text { temperature }\left({ }^{\circ} \mathrm{C}\right)\end{array}$ & $\begin{array}{l}\text { Range } \\
(\mathrm{bp})\end{array}$ & References \\
\hline INRA189 & F-TACACGCATGTCCTTGTTTCGG & $58^{\circ} \mathrm{C}$ & $148-156$ & (Lui et al. 2003)(Cattle) \\
& R-CTCTGCATCTGTCCTGGACTGG & $57^{\circ} \mathrm{C}$ & $147-164$ & (Hooft et al. 2007)(Synceruscaffer) \\
& & $55^{\circ} \mathrm{C}$ & $149-159$ & (Ma et al. 2015)(Chinese yak) \\
\hline
\end{tabular}

found polymorphic in chinese cattle and used for studying genetic diversity Xia et al. (2018). Studies had shown that INRA 189 being present on non-recombinant region of $Y$ chromosome has association with semen quality parameters Deb et al. (2013). Earlier genetic analyses indicated that INRA 189 is a buffalo Y chromosome specific microsatellite (Y-STR), which has 7-8 alleles in African buffalo (Syncerus caffer) population Van Hooft et al. (2007). The principal aims of this study were to screen Y-STR INRA189 marker polymorphisms in five Indian buffalo breeds.

A total of 139 buffalo bulls semen samples were collected from five different breeds (Murrah, Mehsana, Jaffarabadi, Nili-Ravi and Surti). Bulls were selected after screening the pedigree records and unrelated bulls were shortlisted for sample collection. Genomic DNA was extracted from $0.25 \mathrm{ml}$ of semen samples using the standard phenol-chloroform method followed by an ethanol precipitation step Sambrook et al. (2001). The quantity of DNA was analysed using nanospectrometer. Working solution of 50 $\mathrm{ng} / \mu \mathrm{L}$ was made using nuclease free MQ water and was stored at $20^{\circ} \mathrm{C}$ until further analysis. A pair of primer was employed as previously described (Table 1). The forward primer was labelled with 6-FAM fluorescent dye (ABI Prism primer). PCR reaction was performed for INRA189 by using specific set of primers (table 1) in a $15 \mu \mathrm{L}$ of final reaction volume. The final reaction mixture was prepared by mixing $1.5 \mu \mathrm{L}$ of $10 \mathrm{X}$ buffer, $1.5 \mathrm{mM}$ of $\mathrm{MgCl}_{2}$, $200 \mu \mathrm{M}$ dNTPs, $10 \mathrm{pmol}$ of each forward and reverse primer, $1 \mathrm{U}$ of Taq DNA polymerase and approximately $50 \mathrm{ng} / \mu \mathrm{L}$ of genomic DNA as template making up the final volume up to $15 \mu \mathrm{L}$ by adding nuclease free water.The standardized thermocycling protocol for INRA189 was carried out as: Initial denaturation at 
$95^{\circ} \mathrm{C}$ for $5 \mathrm{~min}$, followed by 35 cycles of denaturation at $94^{\circ} \mathrm{C}$ for $30 \mathrm{~s}$, annealing temperature $58^{\circ} \mathrm{C}$ for $30 \mathrm{~s}$ extension at $72^{\circ} \mathrm{C}$ for 30 $\mathrm{s}$ and final extension at $72^{\circ} \mathrm{C}$ for $10 \mathrm{~min}$. The reaction mixture for genotyping of each sample with respect to INRA189 was as follows: For each reaction, $1 \mu \mathrm{L}$ of PCR product, $0.2 \mu \mathrm{L}$ of LIZ 500 and $8.8 \mu \mathrm{L}$ Hi dye were mixed to have a final volume of $10 \mu \mathrm{L}$. The final reaction mixture of 96 samples were taken in genotyping plate consisting of 96 wells for one group at a time. The plate was centrifuged at $1000 \mathrm{rpm}$ for $1 \mathrm{~min}$ to ensure that product is settled at bottom of the well. The plate was then subjected to denaturation at $95^{\circ} \mathrm{C}$ for $5 \mathrm{~min}$ following snap chilling on ice. The prepared plate was then subjected to the capillary electrophoresis on ABI 3730 instruments (Applied Biosystems, USA). Sizing and allele calling was carried out from data generated by capillary electrophoresis by using GeneMapper version 3.7 software (Applied Biosystems). The approximate size range for INRA189 for allele calling was used as per previously reported as shown in table 1 .

In the present study, the results obtained by genotyping INRA189 in 139 male buffalo individuals revealed the presence of only one allele, with sizes of $173 \mathrm{bp}$ (Figure 1). Previously INRA189 was found polymorphic in African buffalo (Syncerus caffer) and showed the presence of different loci: 147-151-156- 158-162 (0), 149-158(1), 147-151-156-164 (2), 147-151-156-162 (3), 160 (4), 147160 (5), 158 (6), 147-158 (7), 147-156 (8), and 149-151 (9) [9]. The presence of different allelic combinations for the INRA189 is due to the multi-locus nature of this marker. In our study difference in $Y$ specific signatures in Indian riverine buffaloes, African buffalo (Syncerus caffer) and cattle can be a possible reason for monomorphism of INRA189 in Indian buffalo breeds.Later, Lui et al. (2003) studied polymorphism in DNA samples of 17 unrelated cattle and found that Y-specific INRA189 was polymorphic. However, in Indian buffalo, INRA189 was found to be monomorphic in reported range of alleles.

\section{Conclusions}

In present study, analysis of INRA189 microsatellite marker in different Indian buffalo breeds reveals the presence of only one allele of size $173 \mathrm{bp}$. Therefore, it is concluded that this marker is monomorphic in Indian buffalo. To best of our knowledge, this is the first report of INRA189 microsatellite marker present on the $Y$ chromosome in Indian breeds of buffalo. Further use of more different kind of Y specific microsatellite markers will clear the trend of $Y$ signature in Indian breeds of buffalo.

\section{Acknowledgements}

Authors are thankful to the Director (s) ICAR-NBAGR, ICARNDRI, ICAR-CIRB and In-charges of different livestock semen stations for providing the full support and help during the entire course of the research work as well as Education division of ICAR for providing financial support.

\section{References}

$19^{\text {th }}$ Livestock Census (2012) All India Report Ministry of Agriculture Department of Animal Husbandry, Dairying and Fisheries.

BAHS (2017) Department of Animal Husbandry, Dairying \&Fisheriy Ministry of Agriculture \& Farmers Welfare Government of India.

Bruford MW, Wayne RK (1993) Microsatellites and their application to population genetic studies. Curr Opinn Genet Dev 3: 939-943

Deb R, Kumar S, Singh U, Tyagi S, Mandal DK, Sengar G, Singh R, Kumar M, Sharma A (2003) Evaluation of three bovine Y specific microsatellite loci as an alternative biomarker for semen quality traits in crossbred bull. Anim Rep Sci 142: 121-125

Hellborg L, Ellegren H (2004) Low levels of nucleotide diversity in mammalian Y chromosomes. Mol Biol Evol 21: 158-163

Liu WS, Beattie CW, Ponce de Leon FA (2003) Bovine Y chromosome microsatellite polymorphisms. Cytogenet Genome Res 102: 53-58

Liu WS, Mariani P, Beattie CW, Alexander LJ, De Leon FAP (2002) A radiation hybrid map for the bovine $\mathrm{Y}$ chromosome. Mamm Genome 13: 320-326

Luikart G, Gielly L, Excoffier L, Vigne JD, Bouvet J, Taberlet P (2001) Multiple maternal origins and weak phylogeographic structure in domestic goats. Proc National Acad Sci 98: 5927-5932

National Bureau of Animal Genetic Resources (2019) Animal Genetic Resources of India. http://www. nbagr. res.in/ registered breed.html

Sambrook J, Russell DW. Molecular Cloning (2001). A Laboratory Manual. 3rd ed. Cold Spring Harbor, NY: Cold Spring Harbour Laboratory Press

Van Hooft P, Greyling BJ, Prins HH, Getz WM, Jolles AE, Bastos AD (2007) Selection at the Y chromosome of the African buffalo driven by rainfall. PLoS One, 2: e1086

Xia X, Yao Y, Li C, Zhang F, Qu K, Chen H, Huang B, Lei C (2018) Genetic diversity of Chinese cattle revealed by Y-SNP and Y-STR markers. Anim Genet doi: 10.1111/age.12742. 